\title{
ポルトランドセメント品質に関する研究の最近の傾向 ${ }^{*}$
}

\author{
高野俊 介**
}

\section{1.むえがき}

本邦セメントの品質站戦時中から戦後にかけて, 焙 成用炭の少化, その他, 種々の理由でロらじるしく低 下しそが, その後, 炭質の向上, 設備の改良, 品質管 理の進歩などより，品質急速に回復し，ととに強

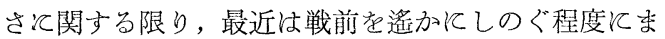

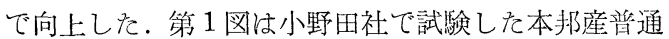
ポルトランドセメントの品質の推移図である。しかし， 現在のセメントは，とのよう飞強さは向上したが，耐 久性その他の面て退歩したとの使用者側の批判もあ る。このとと正にセメント製造沉従事している者に とって反省すべき重要な問題であろう。

次に, 現在の各種セメントの特性と, セメント品質

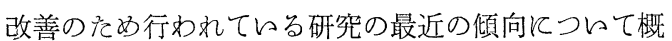
略のべてみたい。

\section{2. 各種ポルトランドセメント，ことにダム用 および道路卌セメントの特性について}

戦後，ダム建設が旺盛となるに和よび，中庸熱七又 ントの需要がロちじるしく多くなり,一方, 産業交通 のめざましい発展とともに，コンクリートによる舗装 が普及され，乙㞦邀するセメントの研究が進展しつ つある。

一般に, 公ムのよう水理構造物に用らるセメント では, 短期強度は多少低くても, 水和熱の值が小さい とと，耐久性が大きいとと，な゙゙が不可欠の条件であ

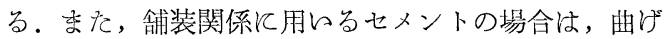
強さ, あるいは引張り強さが大をく, 耐久性が大で, 収縮が小さく，そして延び能力が大きいととなぞが特 飞強調される。乙かし，几和れの場合もその均等性が 強く要望されるととはもちろんである。

\section{（1）強さ}

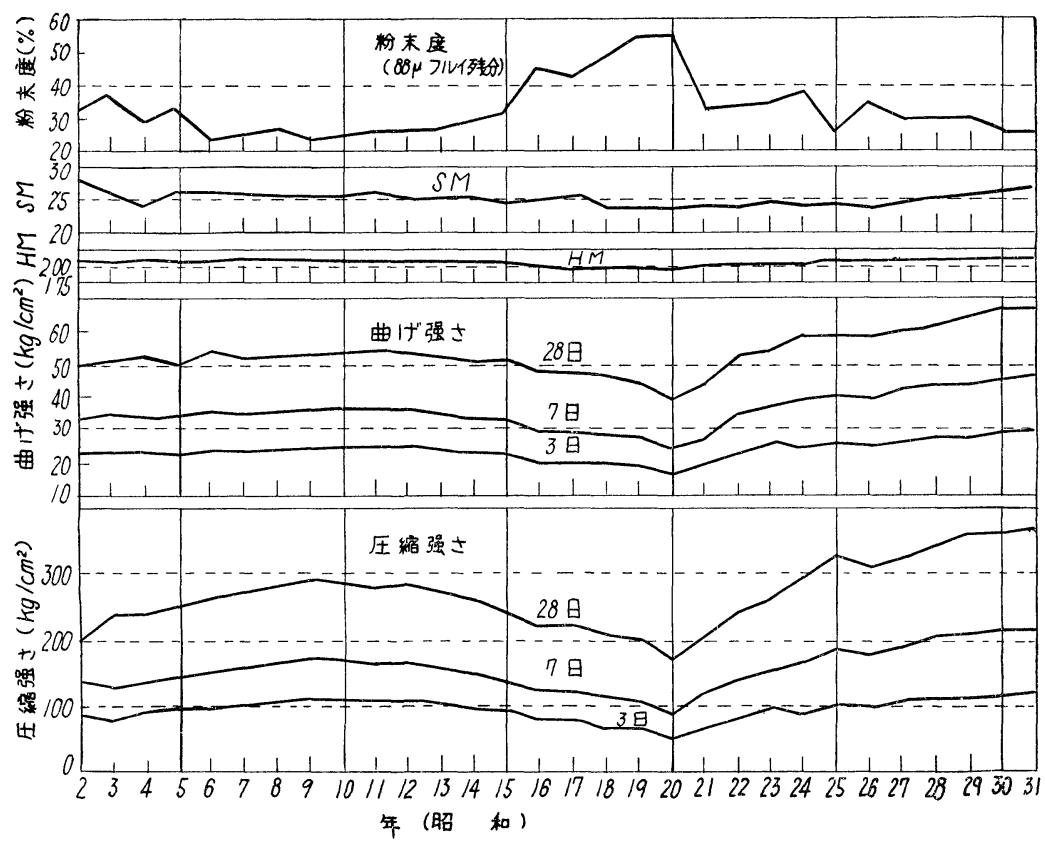

らを, 一般市販の早強, 晋通，中庸熱セメントと， 小野田社で工場規模で大 量試製した道路用セメン トルつけて, これらの特 性を比較すれば第 1,2 表, 和よび第 2 図のようであ ๖.

第 2 表扣よび第 2 図に 示すように，材齢 7 日程 度では, 早強セメントの 強さが最も大きいが，そ の後の強さ增進率は, 道 路用セメント和よび中庸 熱セメントの质らが大を く，材齢 3 筐月ないし 6 箇月以後でね, 道路用七 メント扣よび中庸熱セメ ントの质うが，早強和よ ど普通セメントより強さ が大きい。すなわち，長 (昭和 2 15 の曲げ坑よび圧縮強さは硬練てあるか，すべて現行規格軟練りに換算した。)

期飞わたって強度增進の大きいととがうかがわれる。 ダム内部に政いては，一般に断熱飞近い状態であり， 
第 1 表 各種ポルトランドセメントの特性比較

\begin{tabular}{|c|c|c|c|c|c|c|c|c|c|c|c|c|c|c|c|c|c|c|c|c|c|c|}
\hline \multirow{2}{*}{ 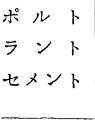 } & \multicolumn{2}{|r|}{ 化 } & \multicolumn{2}{|c|}{ 学 } & 成 & 分 & \multicolumn{3}{|c|}{$(\%)$} & \multicolumn{4}{|c|}{ 成 分 比 率 } & \multicolumn{4}{|c|}{ 鉱物 組 成（\%) } & \multirow{2}{*}{$\left|\begin{array}{l}\text { 扮 末 度 } \\
\text { ブレーン } \\
\left(\mathrm{cm}^{2} / \mathrm{g}\right)\end{array}\right|$} & \multicolumn{2}{|l|}{ 凝 } & 結 & \multirow{2}{*}{$\begin{array}{l}\text { 资 } \\
\text { 定 } \\
\text { 性 }\end{array}$} \\
\hline & Loss & Insol. & $\mathrm{SiO}_{2}$ & $\mathrm{Al}_{2} \mathrm{O}_{3}$ & $\mathrm{Fe}_{2} \mathrm{O}_{3}$ & $\mathrm{CaO}$ & $\mathrm{MgO}$ & $\mathrm{SO}_{3}$ & Total & $\mathrm{SM}$ & AI & $\mathrm{IM}$ & $\mathrm{HM}$ & $\mathrm{C}_{3} \mathrm{~S}$ & $\mathrm{C}_{2} \mathrm{~S}$ & $\mathrm{C}_{3} \mathrm{~A}$ & $\mathrm{C}_{4} \mathrm{AF}$ & & $\begin{array}{c}W / C \\
(\%)\end{array}$ & $\begin{array}{l}\text { 始発 } \\
\text { (时分) }\end{array}$ & $\begin{array}{c}\text { 終結 } \\
\text { (時分) }\end{array}$ & \\
\hline $\begin{array}{l}\text { 道路用 } \\
\text { センント }\end{array}$ & 0.53 & 0.09 & $23 \cdot 09$ & 4.07 & $4 \cdot 19$ & $65 \cdot 45$ & 1.06 & $1 \cdot 35$ & $99 \cdot 83$ & $2 \cdot 80$ & $5 \cdot 670$ & 0.97 & $2 \cdot 065$ & $53 \cdot 9$ & $25 \cdot 5$ & $3 \cdot 7$ & $12 \cdot 7$ & 3150 & 238 & $2-35$ & $3-50$ & 艮 \\
\hline 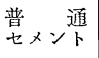 & $\begin{array}{ll}1 & 44\end{array}$ & 0.23 & $21 \cdot 87$ & $4 \cdot 94$ & 312 & $64 \cdot 99$ & 159 & $1 \cdot 29$ & $99 \cdot 47$ & $2 \cdot 71$ & $4 \cdot 431$ & $1 \cdot 58$ & $214^{5}$ & 567 & 200 & $7 \cdot 8$ & 95 & 3440 & $25 \cdot 0$ & $2-35$ & $3-30$ & 良 \\
\hline 早 & $1 \cdot 44$ & 0.07 & $21 \cdot 15$ & $5 \cdot 12$ & $2 \cdot 68$ & $\begin{array}{ll}65 & 16\end{array}$ & 1.48 & $1 \cdot 84$ & 99.94 & $2 \cdot 71$ & $4 \cdot 131$ & $1 \cdot 91$ & $2 \cdot 246$ & $65^{\circ} 0$ & $11 \cdot 7$ & $9 \cdot 2$ & $8 \cdot 2$ & 4320 & 265 & $2-00$ & $2-50$ & 良 \\
\hline $\begin{array}{l}\text { 中霜熱 } \\
\text { セメント }\end{array}$ & 0.92 & 0.21 & $23 \cdot 81$ & 459 & 357 & $63 \cdot 79$ & 1 o8 & 1.05 & 99.62 & $2 \cdot 92$ & $5 \cdot 19$ & $1 \cdot 29$ & 1.97 & 39.8 & $38 \cdot 3$ & 61 & $10 \cdot 9$ & 3270 & $23 \cdot 5$ & $2-53$ & $4-26$ & 良 \\
\hline
\end{tabular}

第 2 表 各種ポルトランドセメントのモル名ル強さ（JIS）

\begin{tabular}{|c|c|c|c|c|c|c|c|c|c|c|}
\hline \multirow{2}{*}{ 七メント種稫 } & \multicolumn{2}{|c|}{ 昍 } & \multicolumn{3}{|c|}{$\left(\mathrm{kg} / \mathrm{cm}^{2}\right)$} & \multicolumn{2}{|c|}{ 压 } & 強 & \multicolumn{2}{|c|}{$\left(\mathrm{kg} / \mathrm{cm}^{2}\right)$} \\
\hline & 3 日 & 7 日 & 28 日 & 3 月 & 1 年 & 3 日 & 7 日 & 28 日 & 3 月 & 1 年 \\
\hline 道路用七メント & $29 \cdot 7$ & $43 \cdot 2$ & $63 \cdot 7$ & $85 \cdot 7$ & 830 & 125 & 191 & 325 & 464 & 488 \\
\hline 偖通セメント & $25 \cdot 7$ & 433 & 663 & $73 \cdot 4$ & 755 & 104 & 198 & 356 & 426 & 459 \\
\hline 早強七メント & 446 & $55 \cdot 0$ & $70 \cdot 2$ & $68 \cdot 2$ & 726 & 197 & 278 & 430 & 452 & 452 \\
\hline 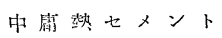 & $23 \cdot 4$ & 336 & $60 \cdot 6$ & $75 \cdot 6$ & 794 & 81 & 156 & 290 & 445 & 480 \\
\hline
\end{tabular}

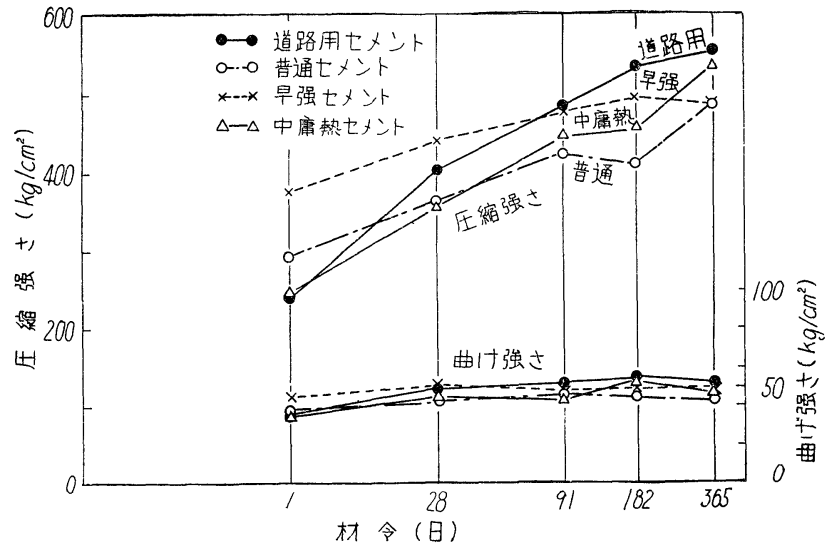

第 2 図 各種ポルトランドセメントのコンクリート強さ

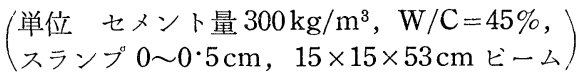

セメントの水和熱により硬化過程にあるコンクリート 体の内部温度は, 打込時よりも, 約 $20 \sim 30^{\circ} \mathrm{C}$ も上昇 するし, 内部温度が最高的 $60^{\circ} \mathrm{C}$ 亿達するととも少な
くはない。とのように常温より高い温度 でセメントが硬化するとを，発現する強 さは常温の場合といちじるしく異なるは ボである、第 2 表执よび第 3 図はその 1 例在示す。

すなわち, 普通セメントと中庸熱セメ ントとで造ったモルタルの圧縮強さを比 較すると，材㱓28日までに和いて，養生 温度 $20^{\circ} \mathrm{C}$ の場合, 普通セメントのほ がはるかに強さが大きいが，養生温度 $40^{\circ} \mathrm{C}$ (ただし, 最初の 1 日は $20^{\circ} \mathrm{C}$, 以 後 $40^{\circ} \mathrm{C}$ ) の場合は中庸熱せメントの在ら が,むしろ強さは大的傾向在示してい る.

以上のような諸事实は養生方法, 温度, 材龄などの養生条件によって, セメント の種類にもとづく強度発現状態が異索ることを示すも のである。これはかって吉田德次郎博士が指摘され， 著者もまた土木学会論交集第26号(p.32〜33)でのべた

第 3 表 中庸熱セメント执よび普通セメント

\begin{tabular}{|c|c|c|c|c|c|c|c|c|c|c|c|c|c|c|c|c|c|c|c|c|c|}
\hline \multirow{2}{*}{$\begin{array}{l}\text { ポルト } \\
\text { ラント } \\
\text { セメント }\end{array}$} & \multicolumn{4}{|c|}{ 化 } & 成 & 分 & \multicolumn{3}{|c|}{$(\%)$} & \multicolumn{4}{|c|}{ 成 分 此率 } & \multicolumn{4}{|c|}{ 鉱物 組 成 (\%) } & \multirow{2}{*}{$\left|\begin{array}{c}\text { 粉末度 } \\
\text { フレーン } \\
\left(\mathrm{cm}^{2} / \mathrm{g}\right)\end{array}\right|$} & \multicolumn{2}{|c|}{ 凝 結 } & $\begin{array}{l}\text { 水和熱 } \\
(\mathrm{Cal} / \mathrm{g})\end{array}$ \\
\hline & Loss & Insol & $\mathrm{SiO}_{2}$ & $\mathrm{Al}_{2} \mathrm{O}_{3}$ & $\mathrm{Fe}_{2} \mathrm{O}_{3}$ & $\mathrm{CaO}$ & $\mathrm{MgO}$ & $\mathrm{SO}_{3}$ & Total & $\mathrm{SM}$ & $\mathrm{AI}$ & $\mathrm{IM}$ & $\mathrm{HM}$ & $\mathrm{C}_{3} \mathrm{~S}$ & $\mathrm{C}_{2} \mathrm{~S}$ & $\mathrm{C}_{3} \mathrm{~A}$ & $\mathrm{C}_{4} \mathrm{AF}$ & & $\begin{array}{l}\text { 始発 } \\
\text { (時分) }\end{array}$ & $\begin{array}{l}\text { 終結 } \\
\text { (捱分) }\end{array}$ & 7 月 28 日 \\
\hline $\begin{array}{l}\text { 中㴋梧 } \mathrm{A} \\
\text { セメント }\end{array}$ & $\begin{array}{ll}0 & 79\end{array}$ & 0.39 & $23 \cdot 99$ & 3.87 & 399 & 6323 & $2 \cdot 19$ & 1.29 & $99 \cdot 74$ & 3.016 & $6 \cdot 20$ & $\left|\begin{array}{ll}0 & 97\end{array}\right|$ & $1 \cdot 95$ & $38 \cdot 9$ & 39.5 & $3 \cdot 5$ & $12 \cdot 1$ & 2840 & $5-45$ & $7-05$ & $55 \cdot 266 \cdot 2$ \\
\hline $\begin{array}{l}\text { 中庸赫B } \\
\text { セメント }\end{array}$ & 0.65 & 0.60 & $23 \cdot 17$ & $4 \cdot 32$ & $4 \cdot 03$ & $63 \cdot 55$ & 1.81 & $1 \cdot 33$ & $99 \cdot 46$ & $2 \cdot 775$ & $5 \cdot 3 \hat{6}$ & 1.07 & 1.99 & $42 \cdot 6$ & $34 \cdot 4$ & $4 \cdot 6$ & $12 \cdot 3$ & 3120 & $3-28$ & $4-30$ & 61.678 .5 \\
\hline 亚メン通 & $1 \cdot 11$ & 0.47 & $22 \cdot 29$ & $4 \cdot 75$ & $3 \cdot 07$ & $65 \cdot 47$ & $1 \cdot 36$ & 1.00 & $99 \cdot 5$ & $2 \cdot 854$ & $4 \cdot 69$ & 1.55 & $2 \cdot 15$ & $54 \cdot 8$ & $\mid 22 \cdot 6$ & $7 \cdot 4$ & $9 \cdot 3$ & 3200 & $4-35$ & $5-41$ & $70 \cdot 286 \cdot 6$ \\
\hline
\end{tabular}




高野俊介

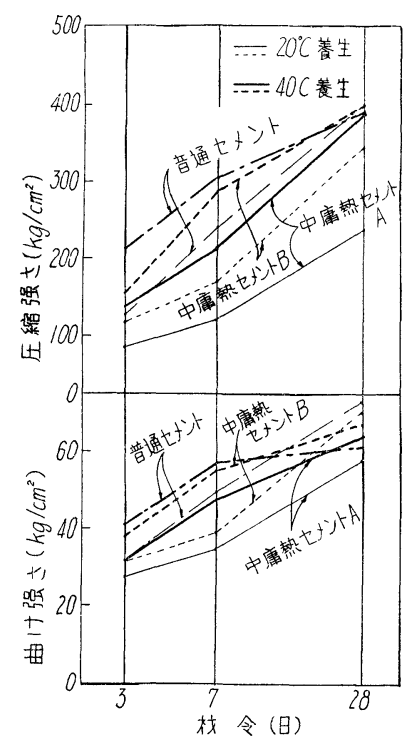

第3図 中庸熱セxントの羪生 温度によるモルタル強さの比 較 (JIS R $520140^{\circ} \mathrm{C}$ の場合 1 日 $20^{\circ} \mathrm{C}$ 湿空以後 $40^{\circ} \mathrm{C}$ 水 中養生)
ように，一律に同 じ養生条件により 各種セメントの強 さの優劣を比較判 定するととは，そ れぞれのセメント の使用目的からみ て合理的でないと 思う。ととにダム のようなマスコン クリートの内部高 温度执よび施工時 の気温, ある々は 打込温度などにつ いて考えると季, 標準温度 $\left(20^{\circ} \mathrm{C}\right.$, 水中）で養生し， しかも材齢28日ま での供試体の強度 侮起もって, セメ ソト品質の優劣を
論議し, あるいは実際のマスコンクリートの強度を推 定してみても，実際的な意義な少ないと思う。

\section{（2）安泰性}

前述のように, 最近の本邦普通セメントは比較的短 期材齢においてはいちじるしく高強度となったが, 七 メントの使用目的から考えて一般にセメントに最も要 求される性質は, 強度よりむしろ構造物の長期にわた る安泰性である。前述の道路用セメントの場合は, 長 期にわたり強度が增進するのみならす，また，第 4 表, 第 4 図に示すように収縮が小さく, 刍裂発生の危険性 が小さら，とのような特性は道路の場合ばかりでなく， 一般構造物にも要求されるととろである。しかし, 近 来, しばしば需要家が強さを重視するのあまり, にた 和ら短期高強度セメントを要望し，しかもコンクリ 一トの所要強度が低いととから,むやみてセメント使 用量㕝減じ, また, その結果, 単位水量を增し, 水比 の大きいコンクリートとなして, 密実性, 耐久性を減 じ, 収縮が大きく, 結果に扸的安泰性を欠くコンク リートを造る場合がはなはだ遺憾である。

\section{i ）長期強さの低下問題}

米国に和々て, PCA 孛中心に 1940 年頃から，セメ

第 4 表 各種ポルトランドセメントのモルタル执よどコンクリートの収縮

\begin{tabular}{|c|c|c|c|c|c|c|c|c|c|c|c|c|c|c|c|c|c|}
\hline \multirow{2}{*}{ ポルトランドセメント } & \multicolumn{9}{|c|}{ モルタル 收 檤 $(\mathrm{ASTM}) \times 10^{-4}$} & \multicolumn{8}{|c|}{ コンクリート收縮 $(15 \times 15 \times 53 \mathrm{~cm}) \times 10^{-4}$} \\
\hline & 3 日 & 7 日 & 14日 & 28日 & 56日 & 3 月 & 6 月 & 9 月 & 10月 & 3 日 & 7 日 & 14日 & 28 日 & 56 日 & 3 月 & 6 月 & 1 年 \\
\hline 道路用セメント & $3 \cdot 1$ & $5 \cdot 4$ & $7 \cdot 9$ & $9 \cdot 2$ & $10 \cdot 4$ & $10 \cdot 6$ & $10 \cdot 7$ & $11 \cdot 3$ & $11 \cdot 3$ & $0 \cdot 51$ & $1 \cdot 17$ & $1 \cdot 41$ & $2 \cdot 26$ & $2 \cdot 84$ & $4 \cdot 04$ & $4 \cdot 23$ & $4 \cdot 59$ \\
\hline 普通セメント & $5 \cdot 2$ & $7 \cdot 4$ & $10 \cdot 3$ & $11 \cdot 0$ & $13 \cdot 2$ & $13 \cdot 5$ & $13 \cdot 4$ & $13 \cdot 8$ & $14 \cdot 2$ & $0 \cdot 64$ & $1 \cdot 13$ & 126 & $2 \cdot 09$ & $3 \cdot 46$ & 430 & $4 \cdot 69$ & $4 \cdot 95$ \\
\hline 早強セメント & $3 \cdot 9$ & $6 \cdot 0$ & $7 \cdot 5$ & $9 \cdot 1$ & $10 \cdot 8$ & $10 \cdot 8$ & $10 \cdot 9$ & $11 \cdot 2$ & $11 \cdot 3$ & $0 \cdot 76$ & $1 \cdot 11$ & $1 \cdot 80$ & $2 \cdot 56$ & $3 \cdot 17$ & $3 \cdot 85$ & 439 & $4 \cdot 50$ \\
\hline 中庸熱セメント & $5 \cdot 9$ & $8 \cdot 0$ & 106 & $12 \cdot 1$ & $13 \cdot 0$ & $13 \cdot 3$ & $13 \cdot 7$ & $14 \cdot 4$ & $14 \cdot 3$ & 091 & 147 & $1 \cdot 66$ & $2 \cdot 62$ & $3 \cdot 51$ & $4 \cdot 43$ & $4 \cdot 83$ & $4 \cdot 97$ \\
\hline
\end{tabular}

（モルタル；1:2.75 オノタワ砂 $\mathrm{W} / \mathrm{C}=0.50 \sim 00^{\circ} 52,2^{\prime \prime} \times 2^{\prime \prime} \times 11^{\prime \prime} 28$ 日水中盖生後初基長，以後 $45 \%$ 湿度内）

（コンクリート；配合前同し， $15 \times 15 \times 53 \mathrm{~cm} ， 7$ 日水中養生後初卙長以後 $55 \pm 5 \%$ 湿度内）

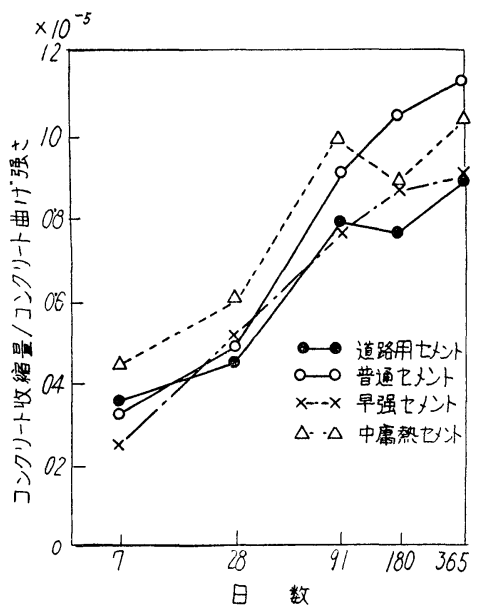

第 4 図 各種ポルトランドセメントの 英裂発生危険率
ント，コンクリートに関する大規榄な長期試験が行わ れているが，第 5 図に示すよらに材齢 5 年までの試験 成績では，モルタルの曲げ，王縮および引張り強さな ビが長年月後低下する傾向があること, 特に Type III (早強) 秋よび Type I (普通)セメントに执いてその傾 向が顕著であるとと，ただし，コンクリートの場合は 低下現象はみら饥かったとと，などを報告している。

小野田社に和々ても, 従来加一般の市肘七メンに つレてモルタル，叔びコンクリートの強さの長期試 験を多数行ってきれが，戦前和よび戦後の試験結果の 一部を第 6 図に示す。図でわかるように，モルタル叔 よびュンクリートの強さはいすれれも材齢 3 䉪月以上で は試験值が上下しているものがかなり多いが，材齢 2 年以上 5 年, 10 年己長期材龄を通じてとれを観察すれ ば，コンクリート強さは一般にわずかずつ増大する傾 向がみら礼る。しかし，モルタル強さは上下し索がら 


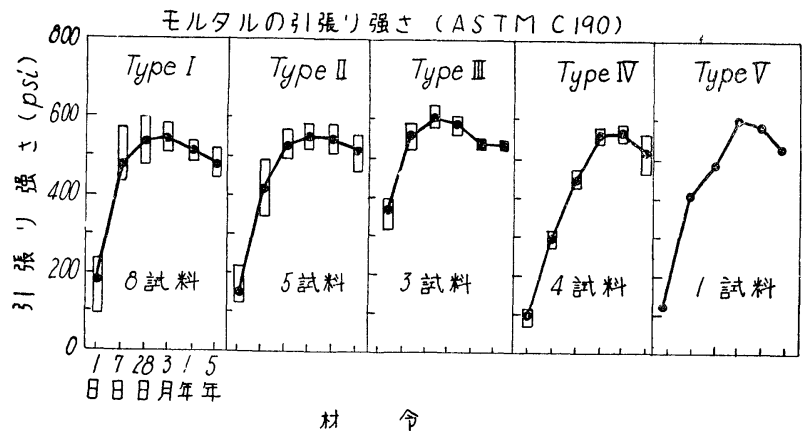

モルタルの圧䋉强さ（ASTMC109）

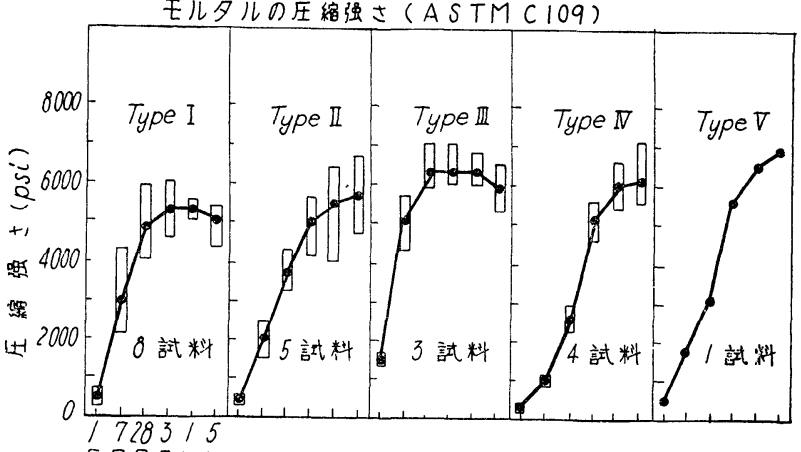

日昌日年年

材令

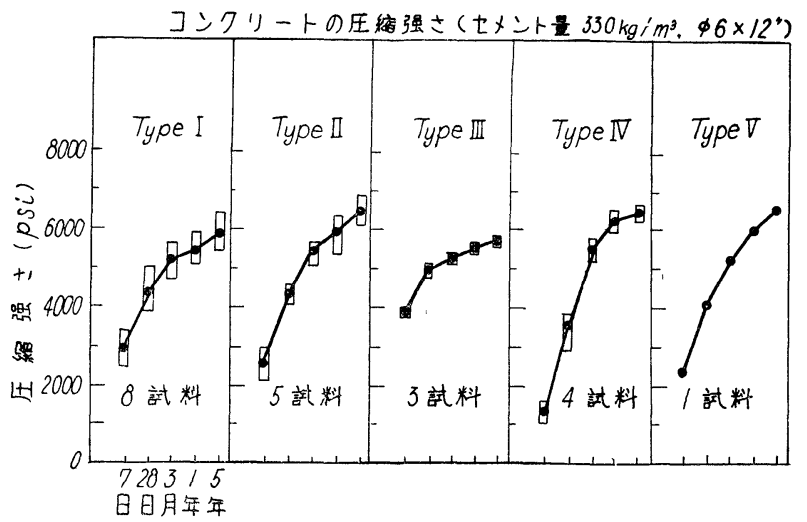

材

第 5 図 米国に扣けるモルタル，コンクリートの 長期強さ試験結果

も, 徐々飞わずかすつ低下の傾向を示しているものが 早強和よび普通セメントに少数ながら見られる。る， 中庸熱セメントに和々ても, 材龄 3 箇月以後モルタル 強さが大きく上下し, 低下の疑らのあるものもある。

一方, コンクリートの強さは, モルタルの強さが低 下の傾向を示している場合でも，ほとんど低下せず， むしろ増大している.モルタル強さ低下の現象につい ては, 前記 PCA などでもあまり問題にしていないし， また，その原因が試験法そのものの欠陷によるものか， あるいはセメントの本質からくるものか，とれを明ら かにするととは，乙の際きわめて大切である。しかし，
そのいずれにせよ決して好ましいものでは なく, 特に材齢 1 年以前に扣いてモルタル 強さが大きく変動するどときは注意を要す ると思う。

\section{ii）長期強さとセメントの品質}

以上の観点から安泰性の 1 つの問題とし て, いかなるセメントが長期にわたり強さ 増進が大きいかを検討してみた。すなわち， 昭和 $29 \sim 30$ 年の本邦市販普通セメント 217 種, 早強セメント 88 種, 中庸熱セメント 47 種, 合計 352 種につ々て, 材齢 1 年までの JIS モルタル強さと粉末度, 化学成分との 相関性を検討してみると第 5 表のよらにあ. る、との結果，注目すべきは，

（イ）普通セメント扣よび中庸熱セメン トの場合，材齢28日から材龄 3 䇢月にわた り，相関性が㐆とえど正から負，または負 から正へ逆転するととである。乙のととは 中庸熱セメントに和いて特にいちじるし ロ.すなわち, 普通セメント, ことに中庸 熱セメントの場合, 短期強さを増大するよ うな事項は長期強さの増進の割合を小さく する傾向があるととを示すものであって， 一般に長期強さを重要とする中庸熱セメン トルたいし，材齢28日以前の短期材齢の試 験值をもってその品質の良否をとやかく言 らととの不合理を,ここに再び強調したい。

（口）全般的な傾向としてブレーン值を 高くするととは長期強さにとって不利であ り，また，鉄率 (IM) は低々在らが長期強 さにとって有利であるが，このととは粉末 があらく $\mathrm{C}_{3} \mathrm{~A}$ 含有量の少ないセメントが收 縮が小さいという傾向と一致し, 安泰性の 高いセメントを造るための指標として希望 をいだかせるものである。

\section{3. セメントの均等性}

セメント製造業者として均等な品質のセメントを供 給するととは使用者にたいし重大な責務である。現在 ダム用セメントは, 使用者の仕様書にもとづき, 生産 者, 使用者, 密揬尔協力のもとに均等性の高いセメン トが現場に供給されているが，それ以外の普通セメン ト，早強セメントの場合でも，製造業者注自主的に原 料の採堀, あるいは受け入れから製品出荷に至る各工 程に扣々て, あらゆる努力を均等性の向上飞傾注し, 入念な品質管理在行っている.

第 8 図に小野田社で試験しそ本邦市販の普通ポルト ランドセメントルつを, JIS モルタル材齢 28 日王縮強 
普通ポルトランドセメント＼cjkstart早強ポルトランドセメント 中庸熱ポルトランドセメント

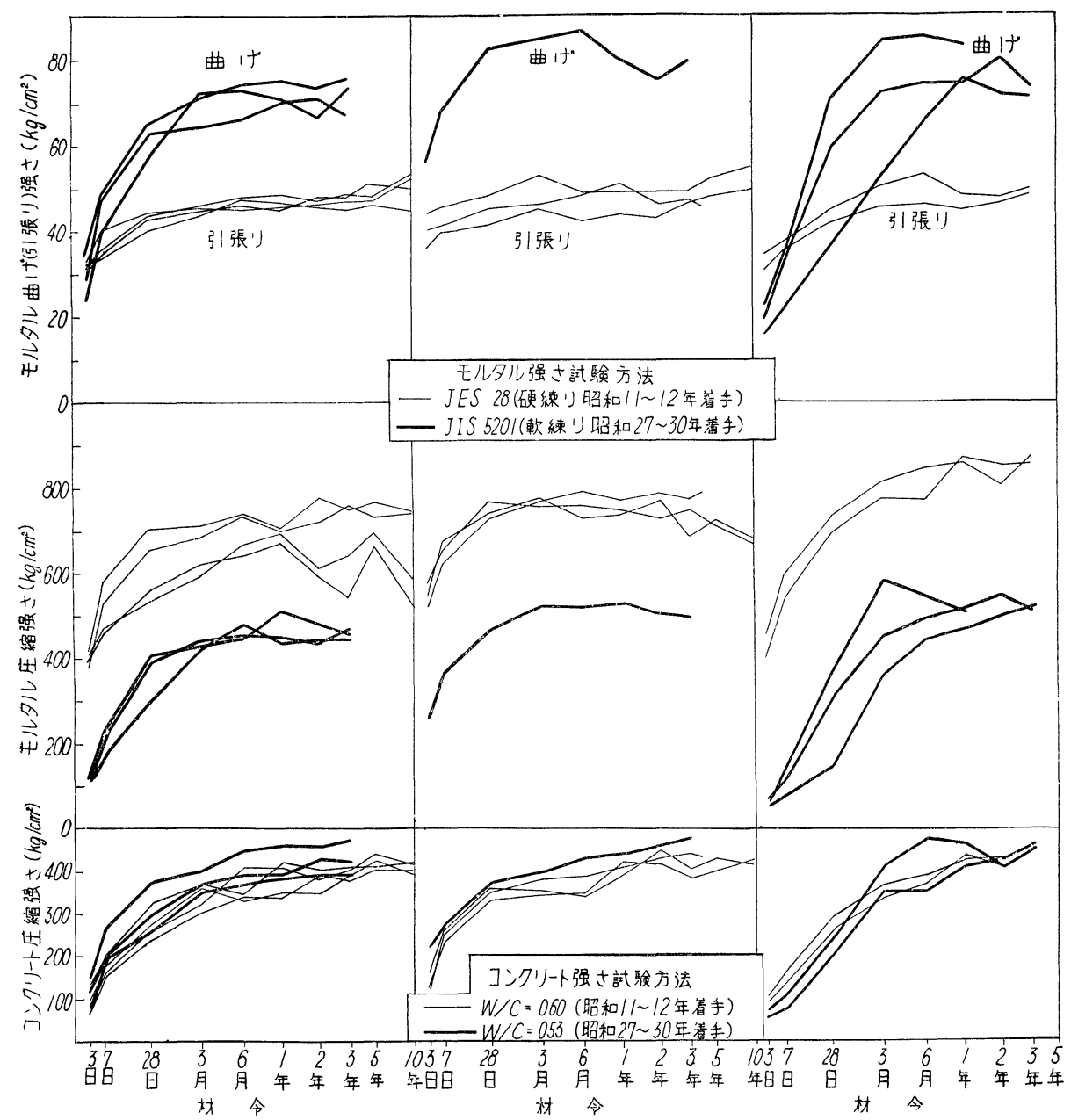

第 6 図各種ポルトランドセメントの長期強さ(そだし, 標準養生による)

さのひん度率の最近 5 綯年間の推移を示す。この図か ら, 昭和 27,28 年頃より最近の昭和 30,31 年の存う が，より均学になっているととがうかがわれる。次に 品質管理の面から近時採り入れられ，また研究されて レる最近の問題につレて述べる.

1) 統計的管理方式の導入

戦後セメント品質管理に和レても他の工業に叔ける 之同様，統計的手法が導入され，管理方式が一層整備 されて意を。すなわち，各製造工程に実験計画法にも とづく工程解析を行うととにより, 変動を与える要因 の所在と, その影響を明らかにし, その改良と, さら 飞作業の標準操作方法を定的, 大量の粉, 塊状物を取 报う原燃料受入れ，各工程のサンプリング方式の改善， ざら飞自動サンプラ一の採用，まを日常管理飞和㚈る 管理図の採用なぞにより変動の発見とその対策並どに 防止飞努め, さらに IBM 統計機, 電子計算機なぞの 採用により，単に一工場ばかりでなく全工場のオーバ
ーコントロールをも集約的に行い, 変動を与える要因 の解析はいちじるしく迅速に行的らるらになっを。

口) 迅速化学分析

迅速化学分析, 特浽器を用的方方法か近時急速飞 発澾しつつある。セメントの品質管理に利いては工程 中の多くの籄所につを数時間叔をに化学分析をなし, それにより化学成分のコントロールを行っているが, この目的のために特飞迅速尔化学分析が要求される。

最近発達したETA試薬支用的る $\mathrm{Ca}, \mathrm{Mg}$ 岁に゙の迅 速容量分析がすでに盛んに用的れているととは周知 のと扒りである。セメント中の $\mathrm{Na}, \mathrm{K}$ の定量は, フ レームフォートメータの使用により督わ容易とな ったが, $\mathrm{Ca}, \mathrm{Mg}$ 飞つレてもフレームフォ一トメータ 飞より定量する研究がまされている。ま机 $\mathrm{Si}, \mathrm{Al}, \mathrm{Fe}$ なぼについては分光光度計の進歩により, 比色法を用 らて定量する方法がすでに一部採用されている。これ らの方法注的礼も試料を的を几分解して水溶液と 
第 5 表 セメントのモルタル強さと粉末度扣よび化学成分との相関性

\begin{tabular}{|c|c|c|c|c|c|c|c|c|c|c|c|c|c|}
\hline \multirow{2}{*}{ セメント種類 } & \multirow{2}{*}{ 試料数 } & \multirow{2}{*}{ 項 } & \multicolumn{2}{|c|}{ 化学成分, 粉末度 } & \multicolumn{3}{|c|}{ 曲げ 強さ } & \multicolumn{2}{|r|}{ 压 } & 絔 & 強 & \multicolumn{2}{|l|}{ さ } \\
\hline & & & 最大 & 最 小 & 91日 & 6 月 & 1 年 & 3 日 & 7 日 & 28日 & 3 月 & 6 月 & 1 年 \\
\hline 早 強 セメント & 88 & $\begin{array}{c}\text { ブレーン值 } \\
40 \sim 15 \mu \\
\mathrm{SM} \\
\mathrm{IM} \\
\mathrm{HM} \\
\mathrm{SO}_{3}\end{array}$ & $\begin{array}{r}4780 \\
42 \\
3 \cdot 00 \\
2 \cdot 06 \\
2 \cdot 30 \\
2 \cdot 84\end{array}$ & $\begin{array}{r}3580 \\
31 \\
2 \cdot 49 \\
1 \cdot 48 \\
2 \cdot 13 \\
1 \cdot 55\end{array}$ & $\begin{array}{l}+0.344^{* * *} \\
+0.344^{*-k} \\
-0.187 \\
+0.215\end{array}$ & & & $\begin{array}{l}+0.293^{* * *} \\
+0.203 \\
-0.113 \\
+0.262^{*}\end{array}$ & $\begin{array}{c}+0.347^{* *} \\
+0.178 \\
(-) \\
+0.274^{* * *}\end{array}$ & $\begin{array}{c}+0.449^{* *} \\
+0.291^{* *} \\
(-) \\
+0.305^{* *}\end{array}$ & $\begin{array}{l}+0.405^{* * *} \\
+0.397\end{array}$ & & \\
\hline 普 通 セメント & 217 & $\begin{array}{c}\text { ブレーン值 } \\
40 \sim 15 \mu \\
\mathrm{SM} \\
\mathrm{IM} \\
\mathrm{HM} \\
\mathrm{SO}_{3}\end{array}$ & $\begin{array}{r}3850 \\
44 \\
295 \\
1 \cdot 84 \\
2 \cdot 15 \\
152\end{array}$ & $\begin{array}{r}3000 \\
30 \\
257 \\
1 \quad 10 \\
2 \cdot 05 \\
0.93\end{array}$ & $\begin{array}{l}+0.181^{* * *} \\
+0.003 \\
-0.082 \\
+0.197^{*}\end{array}$ & $\begin{array}{l}+0.113 \\
+0.259^{*} \\
-0.154^{*} \\
+0.026\end{array}$ & 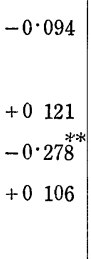 & $\begin{array}{c}-0.290^{* *} \\
(+) \\
+0.063\end{array}$ & $\begin{array}{l}-0.329^{* *} \\
+0193^{* *} \\
+0.055\end{array}$ & $\begin{array}{r}(-) \\
+0 \cdot 178^{* *} \\
+0130\end{array}$ & 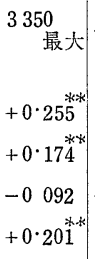 & $\begin{array}{l}-0 \cdot 120 \\
+0 \cdot 244^{* * *} \\
-0 \cdot 002 \\
-0.122\end{array}$ & $\begin{array}{l}-0.313^{* * *} \\
-0.069\end{array}$ \\
\hline 中㴋然セメント & 47 & $\begin{array}{c}\text { ブレーン值 } \\
40 \sim 15 \mu \\
\mathrm{SM} \\
\mathrm{IM} \\
\mathrm{HM} \\
\mathrm{SO}_{3}\end{array}$ & $\begin{array}{r}3380 \\
40 \\
3 \cdot 05 \\
1 \cdot 36 \\
2 \cdot 01 \\
1 \cdot 43\end{array}$ & $\begin{array}{r}2900 \\
33 \\
2.69 \\
0.95 \\
187 \\
0.91\end{array}$ & $\begin{array}{l}+0 \quad 013 \\
-0.474^{* * *} \\
-0.213\end{array}$ & $\begin{array}{l}-0.288 \\
+0.209 \\
-0.401^{*} \\
-0.409^{*} \\
-0.024\end{array}$ & $\begin{array}{c}(+) \\
+0.173 \\
+0.020\end{array}$ & $\begin{array}{l}+0.357^{* * *} \\
-0.419^{* *} \\
+0.400^{* * *} \\
+0.793^{*} \\
+0.480^{* *}\end{array}$ & $\mid \begin{array}{c}+0 \cdot 376^{+* *} \\
(-) \\
+0492^{* * *} \\
+0802^{* * *} \\
+0.434^{* * *}\end{array}$ & $\mid \begin{array}{c}+0.031 \\
-0.525^{* *} \\
(-) \\
(+)\end{array}$ & $\begin{array}{c}(-) \\
-0.415^{* *} \\
-0.541^{* *} \\
-0.359^{*}\end{array}$ & $\mid \begin{array}{c}-0.389^{* * *} \\
(+) \\
-0.678^{* *} \\
-0.766^{* * *} \\
-0.253\end{array}$ & $(+)$ \\
\hline
\end{tabular}

* 有意， ** 高度に有意. +, 一は正および資相䕡を表わす。

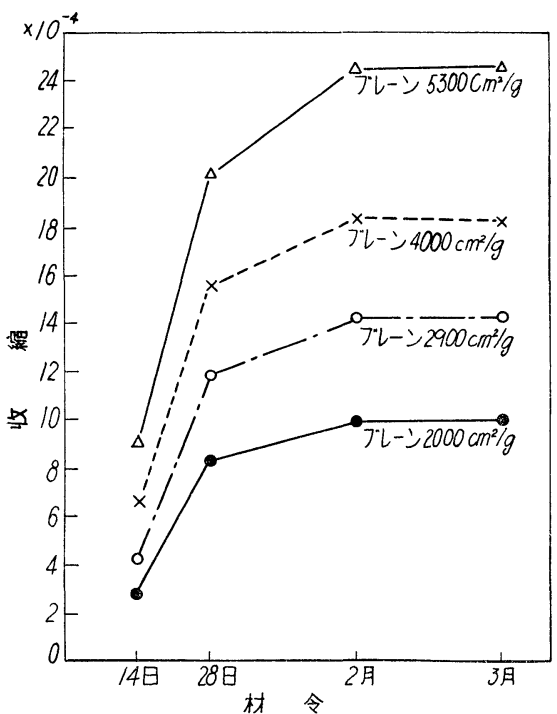

第 7 図 粉末度の異なるセメントのモルタル収縮 $(1: 2,0 \cdot 55,7$ 日水中以後乾燥)

する必要があるが，さらに一歩進んで試料㣽るセメン

ト，あるいは原料を炭素アークにより揮散させて分光 分析をなし，多数の元素につを直読しうる，以わ的る カントメーター式の方法を応用するととが研究されて ロる。

これらの方法の採用により, セメント品質管理の最
第 6 表 セメント中の組成化合物 $1 \%$ あたりの 収縮係数（12简月）

\begin{tabular}{|c|c|c|c|c|}
\hline 組成化合物 & 收 & 緒 & 係 & 数 \\
\hline $\mathrm{C}_{3} \mathrm{~A}$ & \multicolumn{4}{|c|}{$0 \cdot 0 c 234 \pm v^{\circ} 000100$} \\
\hline $\mathrm{C}_{3} \mathrm{~S}$ & \multicolumn{4}{|c|}{$0.00079 \pm 0000036$} \\
\hline $\mathrm{C}_{4} \mathrm{AF}$ & \multicolumn{4}{|c|}{$000049 \pm 0 \cdot 000114$} \\
\hline $\mathrm{C}_{2} \mathrm{~S}$ & \multicolumn{4}{|c|}{$0.00077 \pm 0 \quad 000033$} \\
\hline
\end{tabular}

(H.F Gonnermann, Proc. ASTM, 32 (II), 244 (1934)

大要素の 1 つである化学成分のコントロールは今後, より一層迅速適切と字るであるう。

八） セメント製造のオートメーション化

現在セメント焼成用廻転窯は多くの計器によって原 燃料送入量, 窸廻転数, 暁成带温度, 排ガス温度, 排 ガス成分，ドラフト，1 次空気量和よび温度，2 次空 気温度，クリンカ許出量などを連続的に自動記録し， これらの測定做にもとづき人為的に制御され, いわゆ る計測運転を行っている。しかし，最近これらの計測 装置にさらに制御装置を組合せ，らわゆるオートメ一 ション化先らしめ, 熱効率の増大, せメント品質の均 斉性を向上せしめるべく鋭意研究努力がなされてい る。すなわち, 焼成帯温度計を羔趈転数, 原料, 燃料 送入量調節機に組合わせ，排ガスダンパーまそはフォ ン迴転数をドラフトにより自動制御し，あるいは排ガ 


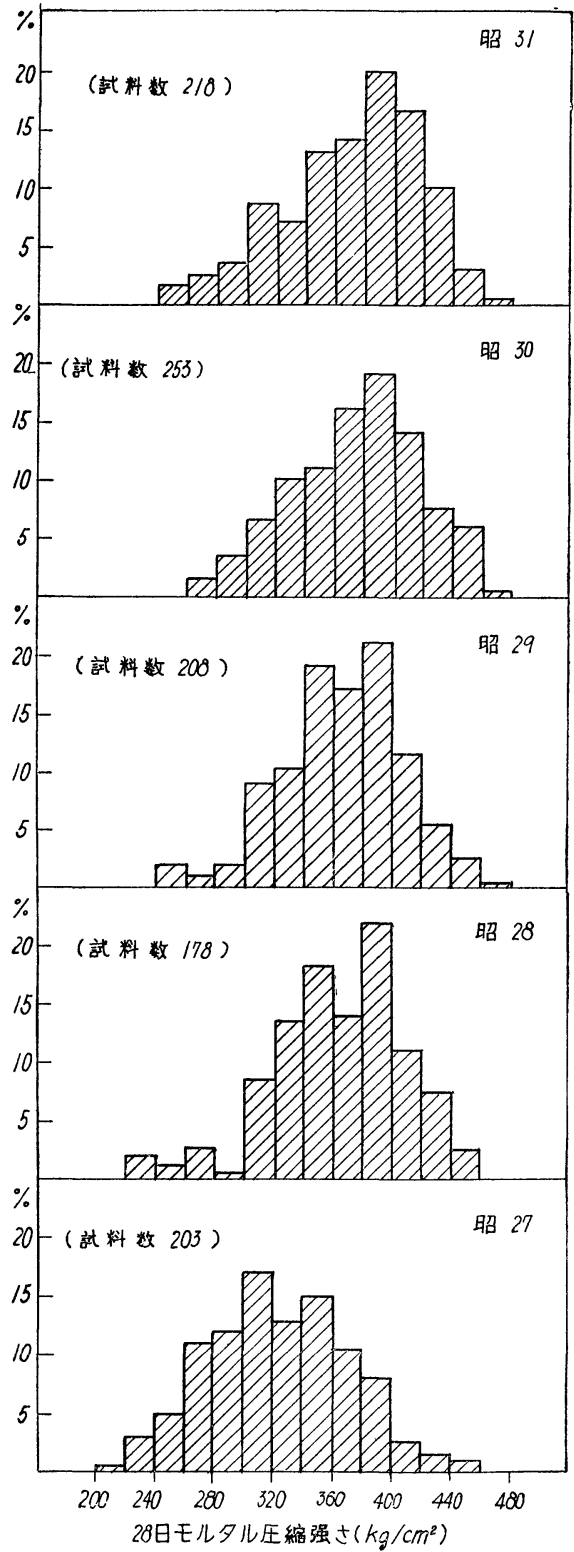

第 8 図 本邦市販普通ポルトランドセメント JIS モルタル 28 日圧縮強さ

ス酸素メーターにより燃料送入量なぞを自動制御与る

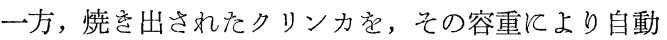
制御するなど多くの方法が考案されている。また, 趈

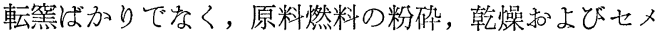
ントの粉础次ても自動制御化が研究されて和り, ことにセメントミルについては粉碚音を利用するミル 運転の自動制御はすでに実用の域に入っている.

\section{4. 要}

1）本邦ポルトランドセメントの品質の推移を示し,
その強さに関する限り, 戦前をはるがしのぐ程度に なっをととをのべ，ポルトランドセメント，乙とにダ ム和よび道路用セメントの特性につレて論じた。

2）安泰性の 1 つの問題として長期飞わをる強さ発 現という点から,

（イ）JIS 法による材龄28日までのモルタル強さを 偏重してはならないとと。

（ロ）米国和よびわが国のセメントモルタル，コン クリートの長期強さ試験結果に和々て，セメントの種 類によっては材齢 1 年以上の長期モルタル強さが低下 する傾向があるとと，また，材齿 1 年以前飞和々ても モルタル強さが大きく変動するセメントがあるとと． しかし，コンクリートでは強度低下の現像はみられす， モルタル強さの低下している場合でもむしろ增大して ロるとと。(そだし，標準養生による)

（八）多数のセメントにつを化学成分, 粉末度と長 期モルタル強さとの相関性を求め結果, 普通七メン ト，特に中庸熱セメントの場合，材齢28日以前の強さ の大をくするための多くの事項は長期材龄，をと完ば 忉龄 3 簀月以後の強さ增進の割合にたいし不利な傾向 があるととなどを論じた。

3）本邦市販セメント均等性はやや向上の傾向があ るとと, まを, セメントの均等性にたいし, 最近セメ ント製造業者が採用し，西るいは研究努力しつつある 事項, 寸なわち, 統計的管理方式の導入, 迅速分析, オートメーション化なぞの現状を説明した。

\section{5.むすび}

今日のセメント扣よびコンクリート技術の発達は， セメントの製造業者と使用者との相互の啓発, 協力飞 よってもたらされたものであるととは申すまでもな レ.今後，セメント製造業者は謭虚索気持で使用者側 の批判, 要望に耳傾け，セメント製造技術の向上を 図り，真僧良な，すなわち，安泰かつ均等質で，し かもそれそれ用途得適合した性質を持ったセメント を経済的に造ることに専念しなければならない。そし て使用者側も，琴今の各種セメントの性質をよく理解 し，特種の場合は別として，、そ蚛短期高強度を 要求するとと京く, 充分にセメントの強度その他の性 質を活用し，セハントの性能の完全なる発揮に努劣 ならば, 明日のセメントコンクリート界の隆盛はさら 飞期待すべをであらう。

注 : 一

1）山恨德治，森茂二郎，セメント技訹年㪕 X (1956)

2) F H. Jackson, Proc. A mer. Concrete Inst., 52, 159 (1955) 